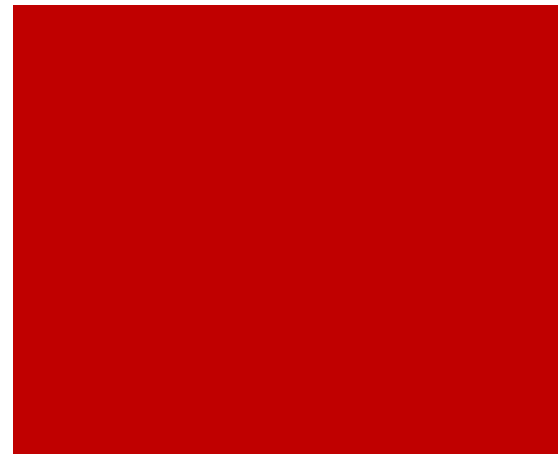

A Revista HISTEDBR On-line publica artigos resultantes de estudos e pesquisas científicas que abordam a educação como

fenômeno social em sua

vinculação com a reflexão histórica

Correspondência ao Autor Nome: Guilherme Torres

Correa

E-mail: correa.gt@usp.br

Instituição: Universidade de São

Paulo, Brasil

Submetido: 06/10/2019

Aprovado: 18/11/2019

Publicado: 30/04/2020

doi> 10.20396/rho.v20i0.8656984 e-Location: e020007

ISSN: 1676-2584

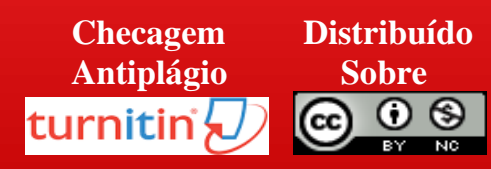

\section{ESBOÇO DE UMA HISTÓRIA DA AULA UNIVERSITÁRIA}

(9) Lattes Guilherme Torres Correa ${ }^{1}$

(D) Lattes Maria Isabel de Almeida ${ }^{2}$

\section{RESUMO}

Este artigo tem como objetivo traçar um esboço de uma história da aula universitária. Justifica-se tal proposta na medida em que se assume a aula como o momento privilegiado de realização do processo educativo na universidade e porque se trata de um objeto relativamente naturalizado pelos sujeitos do campo da pedagogia universitária, que tem se constituído como um campo de práticas, formação e pesquisa sobre a docência na educação superior. Em um primeiro momento, busca-se travar um debate a respeito do conceito de aula, tomando como referência a categoria organização do trabalho didático. Com esse referencial em mente, parte-se para o segundo momento do artigo, no qual busca-se a compreensão dos determinantes históricos da aula universitária.

PALAVRAS-CHAVE: Aula. Universidade. História. Pedagogia universitária. 


\title{
OUTLINE OF A HISTORY OF THE UNIVERSITY CLASS
}

\begin{abstract}
This article aims to outline a history of the university class. Such a proposal is justified insofar as we assume class as the privileged moment of materialization of the educational process in the university and because it is an object relatively naturalized by the subjects of the field of university pedagogy, which has been constituted as a field of practices, training and research on teaching in higher education. At first, we try to establish a debate about the concept of class, taking as a reference the category organization of didactic labor. With this reference in mind, the second part of the article is aimed at understanding the historical determinants of the university class.
\end{abstract}

Keywords: Class. University. History. University pedagogy.

\section{ESBOZO DE UNA HISTORIA DE LA CLASE UNIVERSITARIA}

\section{Resumen}

Este artículo tiene como objetivo trazar un esbozo de una historia de la clase universitaria. Se justifica tal propuesta en la medida en que se asume la clase como el momento privilegiado de realización del proceso educativo en la universidad y porque se trata de un objeto relativamente naturalizado por los sujetos del campo de la pedagogía universitaria, que se ha constituido como un campo de prácticas, formación e investigación sobre la docencia en la educación superior. Al principio, tratamos de establecer un debate sobre el concepto de clase, tomando como referencia la categoría de organización del trabajo didáctico. Con esta referencia en mente, la segunda parte del artículo está dirigida a comprender los determinantes históricos de la clase universitaria.

Palabras clave: Clase. Universidad. Historia. Pedagogía universitaria. 


\section{INTRODUÇÃO}

Este artigo tem como objetivo traçar um esboço de uma história da aula universitária, ou seja, assume como intenção primeira realizar algumas considerações de seus principais determinantes históricos. Trata-se de um trabalho inspirado em uma investigação mais ampla (CORREA, 2016) que se propôs a compreender a aula universitária em suas múltiplas determinações, sobretudo por se configurar como o espaço-tempo predominante de realização do processo educativo na universidade, bem como por ser um objeto relativamente naturalizado, embora não o pareça, pelos sujeitos do campo da pedagogia universitária, que tem se constituído nas últimas décadas como um campo de práticas, formação e pesquisa sobre a docência na educação superior.

Destarte, sentimos a necessidade de contribuir com a compreensão da aula universitária em sua dimensão histórica por meio da discussão de suas diferentes condições de possibilidade ao longo dos séculos ${ }^{3}$, de modo a colaborar na construção deste debate com novos elementos para a discussão do objeto em questão, valendo-se, aqui, de uma perspectiva materialista histórica. Neste sentido, segundo Alves (2005, p. 11),

[...] cada época [...] produz a relação educativa que lhe é peculiar. Isto é, produz uma forma histórica de educador e uma forma histórica de estudante; produz, igualmente, os recursos didáticos e o espaço físico que lhe particularizam, vistos como condições necessárias à sua realização.

E quando assim se expressa, o autor se coloca justamente no horizonte do materialismo histórico (ou da ciência da história, como prefere); e o faz na intenção de investigar a organização do trabalho didático. Esta, de acordo com Alves, varia conforme os modos de produção e suas respectivas fases internas. Como cada matriz teórica possui categorias centrais e subordinadas, o autor comenta que a organização do trabalho didático se apresenta como categoria subordinada, pois produzida no campo educacional, campo até certo ponto distanciado do núcleo de desenvolvimento original do materialismo histórico, a crítica da economia política. Embora uma categoria subordinada, Alves a considera fundamental para o estudo histórico das relações educativas: cada forma concreta de organização do trabalho didático "[...] só pode ser captada concretamente quando referida à forma social que determinou o seu aparecimento, como decorrência de necessidades educacionais dos homens." (ALVES, 2005, p. 17).

De acordo com esta perspectiva, e ao trabalhar no caminho trilhado por Marx, Alves, com a finalidade de compreender a singularidade da escola brasileira, almejou estudar as formas mais desenvolvidas e de tendência universal de seu objeto, isto é, o desenvolvimento histórico da escola nas nações europeias, haja vista aí se encarnar "[...] com maior riqueza a condição de 'sínteses de múltiplas determinações' e pelo caráter universal da sociedade capitalista." (ALVES, 2005, p. 2). Ora, o caso da universidade em muito se assemelha ao da escola. Estudar o desenvolvimento histórico da universidade europeia, como forma mais desenvolvida desta instituição, não deixa de ser uma maneira de lançar "[...] luzes para o entendimento e a

\begin{tabular}{l|l|l|l|l|l} 
(C) Rev. HISTEDBR On-line & Campinas, SP & v.20 & $1-27$ & $\mathrm{e} 020007$ & 2020 \\
\hline
\end{tabular}


configuração dos casos situados fora de sua órbita imediata, inclusive do brasileiro." (ALVES, 2005, p. 2).

Quando Alves (2005) fala em organização do trabalho didático, de certa forma nos fornece os elementos para a conceituação da aula; por conseguinte, nos valeremos desta categoria como guia de nossa reflexão, uma vez que propicia um acesso mais consequente a esse objeto bastante fugidio que é a aula universitária. Desta feita, não consideramos, por um lado, que as categorias organização do trabalho didático e aula sejam equivalentes, por outro, julgamos que a compreensão da primeira categoria possibilita um entendimento mais concreto (no sentido de mais pleno de determinações) da segunda. De nossa parte, imaginamos que aquilo que se convencionou chamar de aula é, na verdade, um momento da organização do trabalho didático, de sorte que a compreensão desta nos coloca diante dos determinantes históricos daquela. Quando apontamos o caráter fugidio da aula universitária, tínhamos em mente a contradição destacada por Freitas (1995), em sua crítica às reflexões de Libâneo (2013), quando este considera a aula como unidade básica de análise do trabalho pedagógico. Na medida em que procura estabelecer uma relação entre ensino e trabalho material produtivo, quer dizer, entre a educação e a categoria fundadora do ser social para o materialismo histórico, Freitas problematiza a assunção da aula como forma básica de organização do ensino, mesmo se numa perspectiva pedagógica crítica, haja vista, para o autor, não se tratar

[...] de criar atividades parecidas com o trabalho material, trata-se da articulação direta com o trabalho material. A aula termina, pois, por remeter-nos à mesma organização do trabalho pedagógico da escola capitalista. A aula é um produto da escola capitalista que assumiu o ensino coletivo (30 alunos para um professor). A natureza coletiva da aula é própria da escola capitalista - está presente na própria arquitetura da escola. (FREITAS, 1995, p. 43).

A inquietação de Freitas reside, fundamentalmente, no fato de Libâneo tomar " [...]a escola capitalista como referência para encontrar sua unidade de análise na didática (a categoria aula), sem criticar esta forma de organização escolar [...]" (FREITAS, 1995, p. 30, grifo do autor), o que significa a ausência do trabalho material como princípio educativo, a falta de relação do processo educativo escolar com o trabalho produtivo concreto, o que reforçaria a dicotomia entre trabalho intelectual e manual, colaborando, pois, com a reprodução da sociedade dividida em classes. Não entraremos aqui em debate com o autor nos pormenores que esta polêmica demanda e merece, debate este realizado por nós na investigação que inspira este artigo, muito embora a nossa própria posição nesta querela tenha se modificado desde então. E se alterou na medida em que estreitamos o diálogo com as produções de Gilberto Luiz Alves, que em um de seus trabalhos (ALVES, 2012), inclusive, polemiza diretamente com Freitas no sentido de defender a maior pertinência teórica de sua categoria "organização do trabalho didático" em relação a outras semelhantes, como "organização do trabalho pedagógico", do próprio Freitas. Dentro do escopo deste artigo, talvez seja suficiente as considerações dos próximos parágrafos. 
Tomemos, inicialmente, a observação que Libâneo (2013, p. 196) faz sobre a aula. Esperamos que a extensão da citação se justifique pelo que vem a seguir:

\begin{abstract}
Se considerarmos o processo de ensino como uma ação conjunta do professor e dos alunos, na qual o professor estimula e dirige atividades em função da aprendizagem dos alunos, podemos dizer que a aula é a forma didática básica de organização do processo de ensino. Cada aula é uma situação didática específica, na qual objetivos e conteúdos se combinam com métodos e formas didáticas, visando fundamentalmente propiciar assimilação ativa de conhecimentos e habilidades pelos alunos. Na aula se realiza, assim, a unidade entre ensino e estudo, como que convergindo nela os elementos constitutivos do processo didático. [...] Em outras palavras, a aula é toda situação didática na qual se põem objetivos, conhecimentos, problemas, desafios, com fins instrutivos e formativos, que incitam as crianças e jovens a aprender. [...] Consideremos, pois, que, na maior parte das vezes, não temos uma aula, mas um conjunto de aulas, visto que os resultados do processo de ensino não são obtidos instantaneamente, e sim pelo trabalho contínuo do professor, estruturado no plano de ensino e nos planos de aulas.
\end{abstract}

Tomemos, agora, a consideração de Alves (2005, p. 10-11) a respeito da organização do trabalho didático, retomando, de forma mais desenvolvida, alguns pontos há pouco apresentados, para percebermos qual a relação entre a categoria organização do trabalho didático e a de aula:

No plano mais genérico e abstrato, qualquer forma histórica de organização do trabalho didático envolve, sistematicamente, três aspectos:

a) ela é, sempre, uma relação educativa que coloca, frente a frente, uma forma histórica de educador, de um lado, e uma forma histórica de educando(s), de outro; b) realiza-se com a mediação de recursos didáticos, envolvendo os procedimentos técnico-pedagógicos do educador, as tecnologias educacionais pertinentes e os conteúdos programados para servir ao processo de transmissão do conhecimento,

c) implica um espaço físico com características peculiares, onde ocorre. (ALVES, 2005, p. 10-11, grifo do autor)

Com tais considerações em mente, e reafirmando um ponto já destacado, julgamos que a categoria organização do trabalho didático se propõe a pensar o processo educativo como um todo, e a categoria aula, por sua vez, busca compreender a situação (didática) específica de materialização do trabalho didático. Na esteira de Marx, Alves nos lembra de que a categoria, como um recurso do pensamento, possibilita captarmos o movimento do real, e que a cada matriz teórica corresponde um sistema hierarquizado de categorias, umas centrais, outras subordinadas. No âmbito do materialismo histórico, Alves sugere que a categoria organização do trabalho didático é uma categoria subordinada a outras como trabalho e organização técnica do trabalho, de modo que as transformações históricas do trabalho didático tornam-se incompreensíveis sem um entendimento das transformações históricas mais gerais do trabalho. É nessa direção que Alves (2005, p. 11) afirma que “[...] uma forma histórica de organização do trabalho didático é o próprio pressuposto consciente da relação educativa correspondente ao seu tempo." Ora, na medida em que assumimos a aula como cada um dos momentos de efetivação da relação educativa, a qual se dá no encontro de uma forma histórica de educador com uma forma histórica de educando(s), num espaço físico determinado, e com a mediação

\begin{tabular}{l|l|l|l|l|l} 
(C) Rev. HISTEDBR On-line & Campinas, SP & v.20 & $1-27$ & $\mathrm{e} 020007$ & 2020 \\
\hline
\end{tabular}


de recursos didáticos específicos, também admitimos que aula é uma categoria subordinada à organização do trabalho didático, deste ponto de vista, uma categoria central, sem a qual é inconcebível compreender a aula em suas múltiplas determinações. Isto posto, embora consideremos extremamente pertinente a crítica de Freitas, porquanto intenta superar a forma atual de organização do trabalho didático (ou trabalho pedagógico, nos seus termos), que se daria especialmente como aula, expressão máxima de separação entre trabalho intelectual e manual, preferimos manter o termo aula não só com o intuito de melhor se comunicar com o campo da Didática e da Pedagogia, mas também porque entendemos, como dito há pouco, que a aula é nada mais que cada um dos momentos de efetivação da relação educativa. Desta maneira, o que há de se superar não é a aula propriamente dita, mas a atual forma capitalista de organização do trabalho didático, o que, evidentemente, só acontecerá com a própria superação do capitalismo como modo de produção.

Assim, podemos dizer que a ideia de aula de que fala Libâneo (2013, p. 196), isto é, “[...] a forma didática básica de organização do processo de ensino [...]" ou "[...] uma situação didática específica [...]", não é outra coisa senão o momento de efetivação da relação educativa (com seus recursos didáticos e espaço físico). E quando falamos em momento, nos referimos exatamente à dimensão temporal: a aula, de certo modo, é a materialização da relação educativa no tempo. Entre outros pontos, a crítica de Freitas (1995) diz respeito ao fato de que no capitalismo, em especial, a relação educativa tem se efetivado apartada da vida, do trabalho produtivo, o que na dimensão espacial se reflete na sala de aula como espaço predominante de efetivação da relação educativa, de sorte que a vida e o trabalho se apresentam apenas no âmbito dos conteúdos, mesmo aqueles mais críticos. No entanto, como a relação educativa não se materializa apenas na dimensão espacial, mas também na temporal, também podemos falar da aula, tal como anunciado no começo do artigo, como o espaço-tempo predominante de realização do processo educativo (formal). Não se trata apenas do capital instaurar e universalizar um espaço específico de realização do processo educativo, afastando-o da relação imediata com as contradições da vida e do trabalho: a escola de massas e suas salas. Trata-se, também, de instaurar e universalizar um tempo específico (fragmentado, racionalizado, controlado, progressivo, hierarquizado) de realização deste processo, o tempo escolar burocratizado e abstrato, cuja lógica não poderia deixar de determinar a própria aula. Tal processo histórico de transformação da organização espacial e temporal do trabalho didático, que se deu conforme a demanda crescente e paulatina por escolarização da sociedade ocidental, passando de uma relação educativa de natureza individual na sociedade escravista e feudal sem um espaço físico institucionalizado para tanto, em que o mestre ou preceptor dominava plenamente o seu processo de trabalho, incluindo a definição da duração de cada um dos encontros pedagógicos - a uma relação educativa eminentemente coletiva no capitalismo contemporâneo - com um espaço físico extremamente institucionalizado, em que o professor tem cada vez menos controle sobre o seu processo de trabalho, em especial na definição da duração de cada encontro pedagógico -, desenhou-se na direção da proletarização do trabalho didático. (TUMOLO; FONTANA, 2008). O problema, logo, não é a aula em si, mas o fato de

\begin{tabular}{l|l|l|l|l|l} 
(C) Rev. HISTEDBR On-line & Campinas, SP & v.20 & $1-27$ & $\mathrm{e} 020007$ & 2020 \\
\hline
\end{tabular}


ter restado ao professor da escola capitalista basicamente a aula: de trabalhador com pleno domínio de sua atividade, na qual a aula era o seu auge, a "[...] responsável pelas operações de ensino executadas dentro da sala de aula [...]" (ALVES, 2012, p. 176), e quase nada mais. Como veremos, o chão histórico da aula universitária em pouco se diferencia desse quadro.

O que buscamos realizar neste artigo, pois, é um esboço de uma história da aula universitária, um esboço no sentido de apresentar algumas reflexões sobre seus principais determinantes históricos, nos baseando, para tanto, nas considerações teóricas desta introdução, em especial aquelas de Gilberto Luiz Alves. Não obstante a investigação deste autor tome como referência principal o trabalho didático na escola, não na universidade, há convergências históricas e estruturais entre ambos os tipos de trabalho didático - dimensão trabalhada por Alves no primeiro capítulo da obra -, o que garante, acreditamos, a possibilidade de "empréstimo" da categoria para refletirmos sobre a aula universitária, o que ao final do artigo pretendemos ter mostrado ser o caso. Assim sendo, para compreendermos a dinâmica da materialidade viva da aula, a relação educativa em sua concretude, havemos de investigar, entre outros aspectos, as formas históricas de educador e de educando, os recursos didáticos que medeiam a relação entre ambas as figuras, bem como as diversas formas de organização espacial ao longo destes séculos de existência da universidade. Muito embora cada aula seja um acontecimento irrepetível, os determinantes históricos da organização do trabalho didático dão um caráter de particularidade a esse evento singular, a esse momento sem o qual o processo educativo universitário seria mera possibilidade. Destarte, veremos que a história da aula universitária é de certa maneira a história da própria universidade, e não poderia ser de outro modo, mas é também um pouco mais do que isso, e é por esse um pouco mais que as páginas a seguir buscam legitimar sua existência. Por fim, uma última consideração: o nosso recorte histórico, pelos limites deste artigo, cobre do nascimento da universidade ocidental na Europa à implementação desta instituição no Brasil nos anos 1930.

\section{ESBOÇO DE UMA HISTÓRIA - PARTE 1}

Como instituição milenar que até hoje se sustenta, não obstante as diversas crises ao longo de seu percurso histórico, a universidade mantém elementos que datam da época de sua emergência, entre os séculos XII e XIII, na Europa medieval. Originalmente falando, como instituição voltada para o "cultivo" do saber, a universidade já existia em outros lugares, por exemplo, no Marrocos; contudo, é a universidade europeia da Idade Média que servirá de referência para o que se convencionou chamar como tal (CHARLE; VERGER, 1996). Segundo Ponce (1998), o germe das universidades pode ser encontrado nas escolas das catedrais das nascentes cidades medievais. Com o processo de urbanização que já tinha início na Europa, a Igreja necessitava diversificar seus aparelhos ideológicos para manter sua hegemonia política, destarte, as escolas dos monastérios, localizados no campo, não podiam oferecer tal possibilidade, o que demandou a criação de novas escolas nas cidades, as escolas das catedrais. 
Além disso, havia demanda de uma nova forma de instrução tendo em vista o crescimento do comércio nas cidades e o nascimento da burguesia como classe social.

A universidade surge mais ou menos como as demais corporações de artes e ofício desse período histórico de transformação da organização do trabalho; não por acaso, o termo universidade tem sua origem na palavra em latim universitas, utilizada nessa época para se referir a qualquer assembleia corporativa, no caso uma corporação de mestres e discípulos. Alves (2005, p. 19) compara o mestre educador de então com o mestre artesão (e o termo mestre em comum não é acidental), haja vista ambos serem nesta época trabalhadores com domínio pleno de sua atividade, seja na dimensão teórica, seja na dimensão prática: "A organização do trabalho didático, portanto, reproduzia a própria organização técnica do trabalho artesanal"; daí o caráter corporativo assumido pela universidade medieval, similar a seu modo às formas das demais associações de mestres. Manacorda (1996) também relaciona a fundação das universidades à transformação socioeconômica que se operava com o desenvolvimento da economia mercantil das cidades e à sua organização em comunas, de tal forma que é nesse contexto que se dá o aparecimento de mestres livres, os quais poderiam oferecer instrução para as classes emergentes, em especial a burguesia. Tais mestres ou intelectuais urbanos se consideravam artesãos, o seu ofício era o ensino das artes liberais, e na medida em que os artesãos se reuniam em corporações, os mestres também começaram a fazê-lo para defender seus interesses e melhor se organizar; mais ou menos assim nascem as universidades. (MANACORDA, 1996; RUGIU, 1998; PONCE, 1998).

Ademais, porquanto os mestres começam a se organizar para vender os seus serviços, ou estudantes começam a se reunir para contratar os mestres que supririam sua demanda de formação intelectual, inicia-se um processo embrionário de mercantilização do ensino, obviamente não no sentido em que damos ao termo atualmente ao falarmos da privatização da educação, mas no sentido de que a universidade, embora uma instituição medieval, já nasce ligada de certa forma ao modo de organização socioeconômico burguês. No entanto, havia um motivo, de alguma maneira englobando todos os anteriores, inclusive a retomada dos clássicos pelas novas traduções e circulação dos comentadores árabes, que de acordo com tinha mais a ver com uma percepção sobre as necessidades "profissionais" do ensino: o crescimento das escolas se realizava de forma descontrolada e desorganizada, e para controlar tal situação, os mestres estabelecidos decidiram se associar com a intenção de racionalizar este processo e “[...] impor a todos um regime de estudos bem definido, baseado na hierarquia das disciplinas, na leitura sistemática das autoridades obrigatórias, na proibição da leitura dos livros perigosos e finalizando com um sistema coerente de exames e de diplomas." (CHARLE; VERGER, 1996, p. 20).

As disciplinas ministradas nas primeiras universidades eram aquelas consideradas, pela Igreja, dignas de serem ensinadas por sua continuidade com a dita cultura erudita, com o saber mais elaborado até então e em total consonância com sua doutrina. Tais disciplinas eram conhecidas como artes liberais, em contraposição às artes mecânicas, consideradas de menor

\begin{tabular}{l|l|l|l|l|l} 
(C) Rev. HISTEDBR On-line & Campinas, SP & v.20 & $1-27$ & $\mathrm{e} 020007$ & 2020 \\
\hline
\end{tabular}


valor, pois ligadas diretamente ao trabalho manual. As artes liberais se dividiam no trivium, ou artes das palavras e dos signos (gramática, retórica e lógica/dialética), e no quadrivium, ou artes das coisas e dos números (aritmética, música, astronomia e geometria); essas disciplinas refletiam as classificações do saber da Antiguidade. É daí que vem a ideia de "Faculdade de Artes", instituição que serviria como um nível propedêutico de acesso aos estudos ditos realmente superiores: teologia, direito e medicina.

Obviamente, a Igreja católica, sob o poder papal, diante da sua necessidade de manter a hegemonia política, não poderia deixar tais corporações desenvolverem vida completamente autônoma, por isso as autoridades superiores eclesiásticas procederam para intervir nas universidades, não exatamente para dominá-las por completo, mas para, num jogo de poder que de certo modo beneficiasse ambos os lados, garantir a autonomia relativa das universidades, mantendo algum controle sobre os conteúdos ministrados, a certificação dos títulos e as práticas aí realizadas, bem como garantindo a formação intelectual de seus próprios quadros; por outro lado, as universidades conseguiam, embora sob a tutela de um poder superior, maior autonomia em relação às autoridades locais e à população das cidades onde se instalavam. No decorrer dos séculos, com a perda de poder central da Igreja e com a emergência dos Estados monárquicos e das Igrejas nacionais, em especial a partir da Reforma Protestante, esse jogo mudaria e as universidades acabariam por sofrer maior intervenção dos poderes estatais/eclesiásticos locais e nacionais, os quais demandavam a formação de quadros profissionais para a burocracia administrativa, que crescia e se complexificava, e também para a elaboração de uma ideologia justificadora do poder agora mais situado na figura dos Estados nacionais.

O público que tinha acesso às universidades no período entre o fim da Idade Média e o Renascimento - público este interessado, segundo Verger (2001), na aquisição de competências precisas (que para a época não poderiam ser exatamente chamadas de profissionais), capazes de oferecer oportunidades de ascensão social e de prosseguimento (seja por desejo pessoal, seja a serviço da Igreja ou do príncipe) numa carreira de secretário de chancelaria, de jurista ou administrador, de médico ou pregador - era composto, sobretudo, por jovens da "classe média" urbana (comerciantes, notários, ricos artesãos etc.). Ponce (1998) mostra que desde os seus primórdios a universidade não se tratou de uma instituição propriamente popular, não só pelas diferentes taxas a serem pagas, mas também pelos diversos rituais. $\mathrm{O}$ autor comenta que a incipiente burguesia tinha, por meio dos estudos universitários, a possibilidade de participar de muitas das vantagens garantidas até então somente à nobreza (com pouco interesse na universidade) e ao clero. Além disso, Verger (1990) lembra que já nesse período entre o fim da Idade Média e o Renascimento, como forma de reprimir aqueles alunos excepcionalmente oriundos de classes desprivilegiadas, mas não somente eles, tem-se a criação de colégios ou pensões mantidos por mestres, que, entre outros aspectos, serviam como dispositivo disciplinar, mantendo-os sob o controle da universidade.

Os mestres dos séculos XII e XIII estavam mais preocupados com a socialização (ainda que bem restrita) do saber erudito, tinham um gosto mais desinteressado pela ciência, confiavam

\begin{tabular}{l|l|l|l|l|l} 
(C) Rev. HISTEDBR On-line & Campinas, SP & v.20 & $1-27$ & $\mathrm{e} 020007$ & 2020 \\
\hline
\end{tabular}


no valor da discussão dos conteúdos com os estudantes, prezavam mais pela estrutura dialética dos debates do que propriamente pelo estilo ou retórica, ensinavam em salas alugadas ou emprestadas, ou mesmo nas suas próprias casas, "[...] no meio dos alunos amontoados, sentados sobre montes de feno, quando as assembleias eram realizadas, ao sabor das possibilidades, na sala de um convento ou na nave de uma igreja [...]" (VERGER, 1990, p. 144), normalmente em condições inadequadas de iluminação e ventilação, raramente mobiliado, "[...] quando muito, com alguns bancos para os alunos e um móvel para o professor.” (PINTO; BUFFA, 2009, p. 23-4).

A partir do século $\mathrm{XV}$, as universidades começaram a ter seus próprios prédios, o que obviamente tem um lado positivo, ainda mais pela necessidade de abrigar as incipientes bibliotecas; contudo, a melhoria das condições materiais de ensino e aprendizagem, com ambientes agora majestosos, aliada ao sentimento de nobreza, levou as universidades a costumes e práticas ainda mais elitizados, principiando pelo vestuário e pelas cerimônias e festas. Ademais, o saber, outrora digno de ser compartilhado, torna-se tesouro, posse. Nesse contexto, Verger (1990, p. 146) argumenta que a relação pedagógica modificara-se por completo, com os estudantes "agora sentados em bancos (a primeira fila era às vezes reservada aos nobres), o professor, vestido com sua toga magistral, pontificava em sua cátedra; era chamado dominus e dava suas aulas como se fossem discursos de aparato. A volta à retórica, favorecida pelo humanismo, apenas agravou essa tendência". Sintetizando a mudança predial da "penúria" ao "esbanjar", que converge com transformações sociais, econômicas e políticas, Gieysztor (1992) comenta que tanto as antigas como as novas universidades já possuíam, no fim do século XV, edifícios próprios para o ensino, como salas de aula, de assembleia, capela, uma ou mais bibliotecas, hospedaria para alunos e mestres, além de muitos artigos de valor. Os edifícios tendiam a ser monumentais, o que significava que as universidades já faziam parte de fato da sociedade, incluindo uma relação mais próxima com as autoridades locais; além de neste momento serem menos móveis, migrantes, como nos primórdios, quando as associações tinham maior possibilidade de mudar de cidade, dependendo dos interesses corporativos e das condições materiais. Com o crescimento das cidades houve também um aumento do número de universidades e seus estabelecimentos de ensino. Os colégios surgiram (e terminaram por absorver muito da Faculdade de Artes) mais ou menos nessa época, incorporados, muitas vezes, às hospedarias, diante de uma situação que tornou mais conveniente aos mestres a realização das aulas nesses espaços, onde a maioria dos estudantes se localizava, em especial porque os serviços das crescentes cidades já não integravam um núcleo central, dificultando a circulação das pessoas.

Sobre o trabalho docente, Verger (1992b) traz elementos que apontam para uma gama extensa de atividades, incluindo administrativas. Segundo o autor, é certo que nem todos os professores eram zelosos com seus deveres, e com base em diferentes documentos, entre eles estatutos universitários e penalidades aos professores, é possível aferir que muitos mestres não cumpriam com seu programa de disciplina, apenas ditavam seus cursos, aprovavam em exames

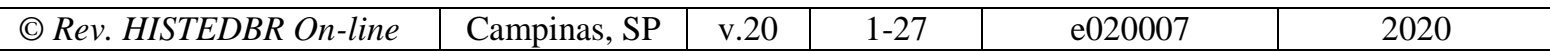


alunos não merecedores, faltavam ao trabalho, colocavam bacharéis ou licenciados para darem aulas nos seus lugares; quer dizer, certas práticas não são "privilégios" da contemporaneidade.

Um ponto fundamental a se destacar nesse contex to é o fato do ensino universitário deste período assumir certos livros como autoridades inquestionáveis, em especial os de Aristóteles. O programa dos estudos era basicamente direcionado no sentido de cumprir a leitura de tais obras. E quando falamos em leitura, não estamos diante de uma metáfora: uma das etapas essenciais do método escolástico de ensino universitário era a lectio (leitura) dos textos em aula. O preparo das aulas exigia o uso permanente dos livros, obras volumosas e caras, o que significava que os estudantes raramente tinham acesso a tais documentos, haja vista a imprensa ainda não ser uma realidade neste momento, tendo que se contentar com cópias realizadas por eles mesmos, com manuais elementares, com fragmentos de leituras ou cadernos incompletos com questões isoladas. A lectio, segundo Coêlho (2008), era uma leitura dos textos-referência feita pelo mestre, que na sequência tecia comentários a respeito, enquanto os alunos tomavam nota, quando havia essa possibilidade. Normalmente, a lectio se dava pela parte da manhã pelos mestres, as aulas ordinárias; enquanto no final da manhã ou na parte da tarde, os alunos mais adiantados, os chamados bacharéis - título (ou condição) dado pelos mestres àqueles estudantes mais avançados nos estudos e que os professores acreditavam já capazes de conduzir algumas leituras ou até mesmo responder alguns debates (que veremos logo a seguir) - tendiam a oferecer algo como um reforço pedagógico ou leitura de temas complementares, as aulas extraordinárias.

Verger (1992a) comenta que a "pedagogia escolástica universitária" (e aqui se trata não apenas da lectio, mas de todos os métodos envolvidos) trouxe uma grande inovação, justamente a articulação entre ensino e avaliação (no sentido que cabe dizer para aquela época). Não obstante o disciplinamento fosse algo bastante presente na universidade deste tempo, a avaliação procedia de forma menos sistemática e controladora que nos dias correntes, até porque neste momento o ensino ainda não era seriado ${ }^{4}$, de modo que o aluno permanecia acompanhando a disciplina o quanto achasse necessário e o quanto pudesse se sustentar para tanto. Os exames eram em sua maioria orais e se realizavam com o objetivo de verificar se o estudante havia alcançado o domínio (o que incluía sua reprodução) dos conteúdos e das técnicas com os quais tivera contato. $\mathrm{O}$ grau de bacharel era oferecido de maneira mais informal pelo mestre; por sua vez, a licentia docendi e o mestrado/doutorado envolviam disputas frente a bancas de especialistas ou mesmo públicas. ${ }^{5}$

O ensino universitário medieval não se restringia a lectio, uma etapa deveras importante, ainda que de caráter até certo ponto propedêutico, de contato com as "autoridades". O núcleo inovador e original da didática escolástica eram as disputas ou questões disputadas (disputatio ou questio disputata $)^{6}$, nascidas das questões mais simples durante os comentários das leituras (a expositio), mas que por seu desenvolvimento ganharam autonomia como um exercício separado e de embate intelectual. Verger comenta sobre a riqueza das disputas - antes de sua decadência como exercício meramente retórico, interesseiro e estilizado -, pois permitiam a

\begin{tabular}{|c|c|c|c|c|}
\hline (C) Rev. HISTEDBR On-line & Campinas, SP & v.20 & $1-27$ & $\mathrm{e} 020007$ \\
\hline
\end{tabular}


abordagem metódica dos verdadeiros problemas filosóficos e científicos. Além disso, haja vista os exames se darem em sua maioria no formato de disputas, esse método permitia um preparo aprofundado dos alunos para estes momentos de avaliação. Contudo, apesar da riqueza das disputas e outros aspectos interessantes, a universidade medieval (e seu ensino) não parece ser um modelo a ser seguido em várias de suas dimensões, sobretudo no seu ponto de vista moralista, tendo em mente que os estudantes eram submetidos a avaliações sobre condutas de vida pessoal, como também no que diz respeito ao acesso, pois, além de classista, nesta época as mulheres estavam excluídas deste tipo de formação.

\section{ESBOÇO DE UMA HISTÓRIA - PARTE 2}

A universidade medieval e a escolástica dariam lugar, entre os séculos XV e XVI, à universidade renascentista e ao humanismo. Isso não significa ruptura completa, mas continuidades e descontinuidades que dialogam com a nova configuração social, cultural, econômica e política que se constituía na Europa ocidental, berço da universidade, nesse período. Ponce (1998) fala de um Renascimento que se propusera formar os homens de negócios que seu tempo demandava, os quais também deveriam ser cidadãos e diplomatas hábeis. No entanto, salienta o autor, embora o burguês do Renascimento, já diante de um capitalismo comercial mais robusto, buscasse romper com o feudalismo teocrático, com a escolástica e o dogmatismo eclesiástico, voltando-se aos antigos e aos ideais greco-romanos, nada havia aí de interesse concreto na modificação da situação dos explorados, não havia dentro do movimento de renovação educativa algo como uma educação popular. $O$ humanismo se colocava na revalorização dos ditos clássicos e da bela latinidade, negligenciados pela universidade medieval seja por controle da Igreja, seja por preconceitos sociais; universidade esta que também havia negligenciado as ciências exatas e as artes mecânicas, tanto por falta de instrumentos de experimentação como por considerar indigno o trabalho manual.

Até mais ou menos o século XVIII, Charle e Verger (1996) falam numa expansão considerável das universidades, incluindo aí as primeiras nas colônias da América, embora o Brasil, como veremos, esperaria um "pouco" mais para ver a sua primeira universidade. Um dos fatores que explicam tal crescimento é a emergência dos estados nacionais ou dos principados territoriais na Alemanha e Itália; ademais, a Reforma Protestante também produziria um número não desprezível de instituições de ensino superior, ainda que em menor número que na Europa católica. Segundo os autores, as antigas universidades medievais continuavam exercendo um papel de relevância no cenário universitário, mantendo, no geral, suas instituições antigas e inspirando novas fundações. Todavia, a estrutura e vida universitárias não seriam as mesmas de antes, inclusive no que tange às concepções educativas, além do processo de nacionalização e regionalização de muitas universidades, deixando de ser instituições que recebiam muitos estudantes de variadas nacionalidades. Enfim, Charle e Verger comentam de uma diversidade institucional que não mais se encaixava na aparente

\begin{tabular}{l|l|l|l|l|l} 
(C) Rev. HISTEDBR On-line & Campinas, SP & v.20 & $1-27$ & $\mathrm{e} 020007$ & 2020 \\
\hline
\end{tabular}


uniformidade da universitas medieval. De todo modo, evidencia-se, nesse processo de evolução institucional das universidades, sua perda de autonomia e uma consequente submissão aos poderes políticos locais.

Conforme Ruëgg (2003), os docentes deste novo período já não se colocavam apenas como mestres dos seus discípulos, mas como formadores das elites sociais e políticas; esse ativismo sociopolítico pessoal, inclusive, de acordo com o autor, seria um dos futuros problemas, já no século XVIII, desta "nova universidade", pois que relegariam a um segundo plano a experiência propriamente intelectual e moral. Em relação ao ensino, Charle e Verger (1996) afirmam que os cursos, sobretudo com o advento dos livros impressos, diminuiriam substancialmente seu tempo de duração se comparados aos da universidade medieval; neste momento, podia-se chegar ao título de licenciado ou de mestrado/doutorado em quatro ou cinco anos. Todavia, parte desta nova configuração temporal também se devia a algo já tangenciado e que neste período moderno se agudizou: o desrespeito aos estatutos, as fraudes nos exames, o absenteísmo professoral, a falta de assiduidade dos estudantes; tudo isso levou não só ao esvaziamento das aulas e das disputas como também facilitou a obtenção dos diferentes graus acadêmicos, obviamente diante de omissão ou acomodação das bancas examinadoras. Charle e Verger (1996) dizem não ser possível precisar o quanto essas práticas se disseminaram pelas universidades, mas afirmam terem sido amplamente difundidas. Frijhoff (2003) fala em dois objetivos das autoridades com as diferentes reformas universitárias deste período: controlar o número de graduados de acordo com a capacidade da sociedade em absorvê-los e ajustar o currículo segundo as demandas profissionais da sociedade. Especialmente em oposição ao segundo aspecto é que, no início do século XIX, o alemão Wilhelm von Humboldt pensaria o modelo de universidade comumente chamada de humboldtiana, onde não deveria haver submissão da universidade às demandas sociais, mas sim ao desenvolvimento do conhecimento.

De interesse maior para o nosso caso é ter havido no século XVIII intenso florescimento de uma atmosfera intelectual em regiões até então menos afetadas pelo humanismo ou por um despotismo esclarecido, como em Portugal, onde os intelectuais nesse momento estavam mais próximos do estado; a universidade se distanciava da Igreja, os déspotas, governantes ou ministros tendiam para um processo de racionalização da universidade e determinavam a ela funções mais relacionadas ao aparelho estatal. Globalmente falando, estamos diante de um processo de expansão, diferenciação e profissionalização da universidade (ou ensino superior, que faz mais sentido neste caso), processo que teria seu amadurecimento na passagem para o século XIX e com a influência mais direta das necessidades e demandas do mercado capitalista.

Nesse período, os colégios ofereciam um estudo cultural geral, até certo ponto menosprezado pelas universidades (quando elas não incorporavam os colégios), estudo que teria nelas algum papel importante posteriormente na faculdade de Direito, que se tornaria um novo lócus de formação geral, e o Brasil seria um bom exemplo deste caso quando da criação de suas primeiras faculdades no século XIX. Muito embora o humanismo tivesse a intenção de alterar o método de ensino escolástico, Brockliss (2003) afirma que o método permaneceu bastante

\begin{tabular}{l|l|l|l|l|l|} 
(C) Rev. HISTEDBR On-line & Campinas, SP & v.20 & $1-27$ & e020007 & 2020 \\
\hline
\end{tabular}


formal e pouco se modificou. Prevaleceu a lectio, com sessões de perguntas e respostas no final das aulas, agora um pouco mais dinâmicas diante da posse de livros ou cópias destes pelos alunos; apesar de sua formalidade, Brockliss comenta da capacidade adaptativa deste método, um dos motivos de sua permanência ao longo destes séculos. Na medida em que as universidades estavam cada vez mais próximas dos aparelhos burocráticos estatais, local onde se inseriam parte considerável dos graduados, Brockliss fala de um interesse mais instrumental de parte dos alunos: menos desejosos de terem acesso a um conteúdo especializado, interessavam-se mesmo pelos diplomas. Esse movimento foi facilitado pelo desenvolvimento da imprensa e da produção dos livros-texto, haja vista a formação não precisar toda ser realizada em sala de aula. Além disso, toda uma rede de ensino informal se constituía, para além das faculdades, sobretudo nos colégios residenciais, onde havia a presença de tutores e o ensino se realizava individualmente ou em pequenos grupos; situação ainda existente, por exemplo, em universidades (ou colleges) inglesas e americanas. No final do século XVIII algumas universidades alemãs começaram a implementar os seminários como um dos métodos oficiais de ensino, com pequenos grupos de alunos avançados ou escolhidos por um professorpesquisador, sendo que neste caso os alunos tinham uma aproximação maior com a dimensão da pesquisa, de modo que não se tratava de uma aceleração da formação, mas um aprofundamento, antecipando o modelo de universidade dito humboldtiano, ou seja, a universidade orientada para a pesquisa. Brockliss comenta sobre a função particular dos dois métodos recorrentes no ensino universitário da época: a leitura, que seria uma forma mais eficiente de ensinar os conteúdos mais importantes e menos controversos para públicos mais amplos e menos avançados; e o seminário, uma forma do professor desenvolver sua contribuição original para o desenvolvimento da disciplina diante de um círculo de "discípulos" ao mesmo tempo críticos e admiradores.

Por sua vez, Vandermeersch (2003) fala sobre o que podemos chamar de quadro docente da época, quando, segundo o autor, a maioria das universidades possuía um pequeno núcleo de professores fixos (mais bem remunerados), em torno do qual havia toda uma gama de auxiliares (doutores, mestres, licenciados, candidatos e bacharéis), os quais podiam ganhar algum sustento com aulas particulares ou tutorias. Outro ponto discutido por Vandermeersch, e de interesse especial para nossa temática, é que no século XVIII, na Alemanha, já se colocava o debate sobre as dimensões pedagógica e científica da prática do professor universitário, se ele deveria ser mais professor ou mais pesquisador, qual papel se subordinaria a qual. Vandermeersch ressalta também que neste período os professores, como indivíduos e como grupo, perderam autonomia de trabalho em relação aos seus pares medievais, especialmente devido à interferência (de diversas ordens, incluindo na seleção de conteúdos) mais intensa dos governos locais.

Apesar de certo prestígio, o trabalho docente tendia a não ser bem remunerado, levando muitos professores a exercerem atividades complementares, sobretudo após a secularização da carreira, de modo que vários deles constituíam família, demandando, assim, um salário ainda maior. Isso implicava, naturalmente, como aponta Vandermeersch, em queda da qualidade do

\begin{tabular}{l|l|l|l|l|l} 
(C) Rev. HISTEDBR On-line & Campinas, SP & v.20 & $1-27$ & $\mathrm{e} 020007$ & 2020 \\
\hline
\end{tabular}


ensino, questão muito atual em nossa educação superior, com uma exploração cada vez mais intensa do trabalho docente. Ainda no que tange às condições de trabalho, o autor comenta datar desse período, principalmente a partir do século XVII, o processo de especialização no ensino, em que os professores começaram a lecionar apenas uma disciplina ou em um único curso; anteriormente não era raro encontrar, por exemplo, professores ministrando aulas de medicina, direito e teologia. Cabe dizer que nas universidades menores, onde o quadro docente era enxuto, muitos professores continuaram por muito tempo a ensinar, por vezes, todo o currículo do curso. Essa caracterização nos aponta um movimento tendencial, o que significa não vivermos atualmente um quadro excepcional, fora da curva. Melhores condições de trabalho e ensino sempre são conquistas de lutas organizadas, do contrário, a tendência é a precarização.

Sobre o acesso estudantil às universidades nesse período, Simone (2003) aborda inicialmente a questão da burocracia do acesso, tanto no que diz respeito às taxas de matrícula, como nos juramentos que os alunos deveriam fazer diante das autoridades universitárias garantindo dedicação não só pedagógica, mas também moral no seu percurso acadêmico. $\mathrm{O}$ perfil dos alunos que acessavam o ensino superior era bastante diversificado, seja em relação à idade, seja do ponto de vista do capital cultural prévio, havendo desde estudantes muito avançados até aqueles sem qualquer instrução; não por acaso, comenta a autora, as faculdades de Artes tornaram-se aquelas com maior público matriculado, e também aquela de menor prestígio. Apesar de algumas tentativas de controle do acesso na dimensão da qualificação prévia, até o fim do século XVIII ainda não havia um sistema estruturado de seleção, o que significa que não havia uma ligação formal entre ensino secundário e superior, papel este realizado até certo ponto pelos colégios, que segundo Simone não deixaram de ser uma forma embrionária de ensino secundário em alguns países, ou formação geral inicial (aquela oferecida normalmente pelas faculdades de Artes) dos cursos universitários, em outros. A autora salienta que o acesso das mulheres ao ensino superior só teria um progresso real a partir do século XIX.

Pinto e Buffa (2009) comentam que nesse período as universidades e colégios continuavam sendo construídos dentro do ambiente urbano, inter-relacionados à cidade. $\mathrm{Na}$ medida em que cresciam, os novos prédios tendiam a ser elevados, se possível, junto aos antigos. Como vimos, a tendência era que fossem suntuosos, com diferentes espaços definidos de acordo com sua função, como as salas de aula e de estudo, dormitórios e bibliotecas. Os colégios eram mais fechados que as universidades, haja vista nos primeiros prevalecer a ideia de comunidade em si mesma, com seus membros vivendo literalmente lá. Uma inovação viria de um país que na verdade era uma colônia britânica, os Estados Unidos da América (EUA). Como colônia da Inglaterra, era de se esperar que os EUA iniciassem sua história acadêmica de forma semelhante, e não por outro motivo os colleges ingleses serviram de inspiração. Contudo, os estadunidenses seguiram adiante, e entre outras coisas, fizeram do colégio uma comunidade ainda mais ampla, por exemplo, construindo refeitórios e espaços recreativos até então nunca vistos numa universidade (ou colégio). Diferentemente dos colégios ingleses - em que, apesar de sua ligação com a cidade, os prédios eram como claustros, com a vida mais voltada para seu 
lado interno -, os colégios estadunidenses eram mais abertos, com edifícios separados. Ademais, eles começaram a ser construídos nos limites das cidades ou mesmo no campo, isso porque havia uma ideia romântica de uma escola afastada das forças corruptoras da cidade, ou, quando nela, que tentasse simular a natureza de alguma forma, valendo-se de áreas muito verdes, por exemplo, ou mesmo de um rio ou lago. Daí surgiria algo realmente novo e com o qual estamos naturalizados: o campus universitário. (PINTO; BUFFA, 2006).

\title{
ESBOÇO DE UMA HISTÓRIA - PARTE 3
}

Na passagem do século XVIII para o XIX e daí em diante, o mundo se encontrava diante de uma nova realidade, justamente a "consagração" do capitalismo como modo de produção dominante, não mais na sua fase mercantil, mas agora na sua fase propriamente industrial, sobretudo após a Revolução Industrial e a Revolução Francesa. Segundo Ponce (1998), com o desenvolvimento das forças produtivas em meio a um capitalismo industrial, a burguesia não podia mais negar a instrução ao povo; as novas máquinas e processos de produção demandavam uma formação mais elevada que o saber miserável de um servo ou escravo, não por acaso no século XIX a escola começaria mais intensamente seu caminho de universalização. Todavia, o capital também demandava tanto trabalhadores especializados, como os altamente especializados. Com a divisão e especialização do trabalho, a burguesia necessitava de uma educação superior capaz de formar seus técnicos e capatazes do exército industrial, assim como o Estado demandava sua burocracia especializada. A diversificação institucional e dos cursos superiores se deu, fundamentalmente, para suprir essa necessidade capitalista; entre as novidades de então, por exemplo, estavam as escolas politécnicas.

A respeito do nosso continente, Charle e Verger (1996, p. 124) procedem com a seguinte síntese:

\begin{abstract}
$\mathrm{Na}$ América Latina, as estruturas herdadas da época colonial demoram a ser novamente questionadas. O movimento de reforma parte de um protesto dos estudantes de Córdoba, na Argentina, em 1918, e ganha pouco a pouco os países vizinhos: Peru, Chile, Uruguai, Colômbia, México, Cuba. Gradativamente, a autonomia universitária viu-se aumentada, os estudantes conseguem um direito de supervisão dos negócios acadêmicos, a seleção dos docentes torna-se mais rigorosa. Por vezes, a modernização é realizada de maneira autoritária, como no Brasil na década de 1930, quando são criadas universidades no Rio de Janeiro e em São Paulo com professores vindos da Europa, particularmente da França.
\end{abstract}

Como se trata, neste trabalho, justamente de pensar a aula universitária no Brasil, pois nosso interesse especial é contribuir com o campo da pedagogia universitária em nossas terras, na sequência procuraremos entender, dentro dos limites deste artigo, como se deu a constituição da educação superior e universidade brasileiras.

Em sua pesquisa, Machado (1999) buscou analisar diferentes discursos sobre a docência universitária, materializados em documentos sobre os quais o autor trabalhou, identificando 
seus elementos e relações para estabelecer duas séries históricas que segundo ele constituíram a docência universitária: uma religiosa-moral e outra científico-política. Segundo o próprio autor, ele procedeu com uma descrição dos discursos constituidores da docência universitária articulando as duas séries históricas ou linhas de força apontadas, de modo que a religiosa-moral se inicia na Idade Média, "[...] com o surgimento das corporações universitárias, que predominou no sistema educacional brasileiro até o final da década de 20, quando principiou o seu enfraquecimento [...]”; por sua vez, a científico-política teve início no Brasil na década de 1930, “[...] com o predomínio de discursos científicos e políticos.” (MACHADO, 1999, p. 9).

Importante ter em mente, como apontado por Machado detalhadamente em seu texto, que a universidade portuguesa, desde sua criação, teve pouca autonomia em relação à monarquia e à Igreja, sofrendo intervenções diretas de todas as ordens (incluindo administrativas e pedagógicas), intervenções, segundo o autor, sem comparação com as demais universidades europeias. Isso nos é caro por conta da relação histórica de estruturação do sistema de educação superior brasileiro com nossa antiga Metrópole, especialmente pelo fato de muitos dos professores deste nível de ensino terem completado sua formação em Coimbra, além da própria chegada da corte em 1808 e a consequente fundação das primeiras escolas profissionais isoladas em território nacional.

No período colonial, o principal aparelho ideológico era a Igreja católica, integrada ao funcionalismo estatal, de tal modo que o que havia de ensino superior nessa época, muito se devia à forma como essa instituição pensava a educação. Segundo Cunha (2007), devido ao número, organização e relevância, entre as ordens religiosas presentes no país, a que mais se destacava, e de nosso interesse, era a Companhia de Jesus. Além de suas atividades de caráter mais missionário, nas cidades mais importantes os jesuítas mantinham colégios para todos os níveis de ensino, incluindo o superior. No que diz respeito ao nosso objeto de estudo, os jesuítas colaboravam com a formação de quadros para o aparelho estatal repressivo (oficiais da Justiça, da Fazenda e da Administração) e para a classe dominante ilustrada local, isto é, filhos de proprietários de terra e minas e de mercadores metropolitanos. De acordo com o autor, e sempre enfocando o nosso objeto, portanto deixando de lado a formação de quadros para o próprio clero, o currículo desses colégios era estruturado basicamente com as ideologias e práticas letradas comuns à cultura das classes dominantes, além das especialidades diversas da burocracia estatal, com o latim como a língua principal. Os estabelecimentos de ensino dos jesuítas seguiam as normas padronizadas pela Ratio Studiorum de 1559, e sua pedagogia se inspirava tanto nas Instituto Oratoria de Quintiliano como na Universidade de Paris, centro de uma importante restauração do pensamento de Tomás de Aquino nos princípios do século XVI; a partir de 1751, a Ratio seria alterada para incluir as línguas vernáculas e conteúdos das ciências naturais, tirando assim o privilégio total do estudo das humanidades.

No Brasil, havia, no âmbito da educação superior nos colégios jesuítas, o curso de Artes, também conhecido como curso de Ciências Naturais ou curso de Filosofia, com duração de três anos, e o curso de Teologia, com duração de quatro. O curso de Artes conferia os graus de

\begin{tabular}{l|l|l|l|l|l|} 
C Rev. HISTEDBR On-line & Campinas, SP & v.20 & $1-27$ & e020007 & 2020
\end{tabular}


bacharel, com uma banca examinadora composta de três pessoas, e o de licenciado (que pretendia exercer o magistério), com uma banca de cinco membros. Os cursos eram destinados tanto a alunos pertencentes à Companhia de Jesus como aos externos, respectivamente os colégios e os internatos. $\mathrm{O}$ curso de Artes foi criado para atender principalmente à demanda de alunos "externos", sem interesse na carreira eclesiástica, servindo como etapa propedêutica aos cursos profissionais (medicina, cânones e direito) da Universidade de Coimbra.

Cunha aponta que o plano pedagógico dos jesuítas no Brasil era o mesmo utilizado na Europa e reproduzia os rituais e solenidades das universidades deste continente. Com o passar do tempo, até a expulsão da Companhia de Jesus do Brasil em 1759, novos colégios foram criados assumindo o Colégio da Bahia como modelo. A Companhia era a principal responsável pela educação superior tanto na Metrópole como na Colônia, mas disputas políticas e econômicas levaram o recente ministro do rei, Marquês de Pombal, num movimento de ampliação de poder do Estado português, a expulsar de Portugal e das colônias a Companhia de Jesus (aliada da oposição). Segundo Cunha, a política pombalina se realizou na tentativa de romper a subordinação portuguesa à Inglaterra e proceder com a industrialização do país, buscando alcançar uma independência econômica, o que concorreu, entre outras coisas, para a tentativa de implementação de ideologias mais concernentes a uma sociedade capitalista de formação mais madura, o que significou a emergência de um programa cultural de caráter, sobretudo, iluminista.

Ao contrário dos jesuítas que se preocupavam, até demais, com a formação docente, após a expulsão da Companhia de Jesus do reino português não se buscou efetivamente uma nova formação de professores para o ensino superior, e justamente por isso Machado (1999) fala da resistência e permanência de uma lógica jesuítica remanescente na base da docência do ensino superior brasileiro, ainda que com o passar do tempo - em especial após a criação das primeiras universidades e da institucionalização das cátedras - os novos conteúdos - agora mais especializados segundo cada campo do conhecimento, e também laicizados, ou seja, menos sujeitos a dogmas religiosos, e mais técnicos e experimentais - começaram a colaborar de alguma forma com a reconfiguração da prática docente.

No Brasil, a expulsão da Companhia de Jesus culminou com a destruição total do sistema educacional escolar colonial, haja vista sua dominação anterior. No seu lugar foram criadas as aulas régias, aulas fragmentadas e isoladas de diferentes matérias enciclopédicas, como, por exemplo, grego, filosofia, retórica e poética, geometria, e aritmética, o que se verificou também no ensino superior. Nesta época, dois cursos superiores mais estruturados foram criados, um no Rio de Janeiro, outro em Olinda. No entanto, de maior interesse para nosso objetivo é o que viria a se realizar após a chegada da corte portuguesa em 1808, com a transferência da sede do poder da Metrópole para o Brasil. Neste momento dava-se a emergência de um Estado nacional, o que segundo Cunha (2007) demandou a modificação completa do ensino superior colonial, com o novo nascendo "[...] sob o signo do Estado nacional, dentro ainda dos marcos da dependência cultural aos quais Portugal estava preso [...]", levando

\begin{tabular}{l|l|l|l|l|l}
\hline (C) Rev. HISTEDBR On-line & Campinas, SP & v.20 & $1-27$ & $\mathrm{e} 020007$ & 2020 \\
\hline
\end{tabular}


à criação de "[...] cursos e academias destinados a formar burocratas para o Estado e especialistas na produção de bens simbólicos; como subproduto, formar profissionais liberais." (CUNHA, 2007, p. 63).

Os burocratas do Estado eram formados, de início, tanto em estabelecimentos militares (como a Academia Militar e a Academia da Marinha), quanto nos cursos de medicina e cirurgia e o de matemática. Com o passar dos anos novos cursos foram sendo criados para a formação de profissionais não militares, como, por exemplo, os de Agronomia e Arquitetura, mas em especial o de Direito, que no âmbito da produção de bens simbólicos, formavam bacharéis que tinham, "[...] na atividade cotidiana de elaborar, discutir, e interpretar as leis, a tarefa principal de formular e renovar ideologias que legitimavam as relações de dominação mantidas e dissimuladas pelo aparato jurídico." (CUNHA, 2007, p. 64). Segundo Cunha, estes profissionais viriam a ser os ideólogos das frações mais progressistas das classes dominantes e camadas médias urbanas. $\mathrm{O}$ autor ainda lembra que o ensino superior desse período pós-1808 até o Primeiro Reinado se estruturou em estabelecimentos isolados e aí se formaria “[...] o núcleo de ensino superior sobre o qual veio a ser edificado o que existe até hoje, ligado à sua origem por ampliação e diferenciação." (CUNHA, 2007, p. 71). Durante todo o Império este nível de ensino não sofreu grandes alterações, permanecendo basicamente o mesmo, sem mudanças substanciais, incluindo a não criação de universidades propriamente ditas. Mais especificamente em relação ao nosso objeto de estudo, afirma Cunha (2007, p. 91) o seguinte:

As primeiras unidades do novo ensino superior apareceram sob a forma de aulas e
cadeiras. Estas eram unidades de ensino de extrema simplicidade, consistindo num
professor que, com seus próprios meios (livros, instrumentos cirúrgicos etc.), ensinava
seus alunos em locais improvisados, fosse um hospital ou sua própria residência. Essas
unidades simples podiam estar aglomeradas em cursos, dotados de reduzida
burocracia. Foram as escolas, academias e faculdades, surgidas mais tarde, as
unidades de ensino superior que possuíam uma direção especializada, programas
sistematizados e organizados conforme uma seriação preestabelecida, funcionários
não docentes, meios de ensino e locais próprios.

Ao longo desse período as aulas e os exames preparatórios sofreram várias alterações (CUNHA, 2007, p. 112-7), por exemplo, no tempo e extensão territorial da validade dos certificados, ou com a criação do Colégio Pedro II, o qual possibilitava acesso direto ao ensino superior, mas sua essência classista de seleção de acesso se manteve, o que se materializava no número limitado de estabelecimentos de ensino superior e de estudantes matriculados, os quais se localizavam em apenas sete cidades. No período histórico seguinte, a Primeira República (1889-1930), essa configuração seria alterada, com aumento do número de faculdades, de matrículas, ampliação do leque de cursos, facilitação do acesso e expansão territorial; além disso, foi nesse período que as primeiras universidades foram criadas no país, vingando entre estas, segundo Cunha, a Universidade do Rio de Janeiro (1920) e a de Minas Gerais (1927). Neste período houve demanda por força de trabalho especializada, o que provocou um aumento no número de faculdades, inclusive as particulares, novidade até então. Ademais, o sistema educacional tinha como uma de suas funções primordiais fornecer diplomas que garantissem

\begin{tabular}{l|l|l|l|l|l} 
(C) Rev. HISTEDBR On-line & Campinas, SP & v.20 & $1-27$ & $\mathrm{e} 020007$ & 2020 \\
\hline
\end{tabular}


acesso a posições de poder, porém, essa função seria ameaçada justamente pelo aumento do número de diplomados, que tendiam a ser menos raros e assim perdiam ou tinham diminuído o seu poder discriminador, situação que tentou ser superada ou amenizada pela implementação dos exames vestibulares para o acesso aos cursos superiores. Cabe lembrar, com o autor que, embora em grande parte estatal, o ensino superior nessa época não era exatamente gratuito, $o$ que indicava ainda mais seu caráter classista, não muito diferente do que vimos sobre a universidade europeia; havia toda a sorte de taxas acadêmicas: de vestibular, de matrícula, de frequência em cada série, de frequência de cadeira dependente, de exame, de transferência.

Durante esta época não foi política do governo federal, em especial por ação dos positivistas, a criação de universidades. Todavia, o jogo político das diferentes frações das classes dominantes abriu brechas para que algumas tentativas de criação de universidades fossem realizadas, como a Universidade de Manaus (1909-1926), a Universidade de São Paulo (1911-1917) e a Universidade do Paraná (1912-1915), muito rapidamente abortadas pela correlação de forças da época, prevalecendo a vontade do governo federal em relação às forças estaduais. Entretanto, diante do quadro de instituições universitárias começando a surgir à revelia do poder central, inclusive uma de caráter duradouro (a Universidade de Minas Gerais em 1927), o governo federal possivelmente sentiu necessidade de controlar novas iniciativas valendo-se exatamente do mesmo dispositivo, isto é, a criação de universidades, mas agora sob seus auspícios, implementando, ao longo dos anos, novo ordenamento jurídico regulador de sua criação. A Universidade do Rio de Janeiro, criada em 1920, por decreto federal, daria o tom do modelo de organização de nossas universidades, modelo este sistematicamente criticado por Florestan Fernandes $(1975 ; 1984)$ : a mera justaposição de faculdades isoladas, sem qualquer forma de integração.

Neste contexto, a partir da transição para a implementação das primeiras universidades no país, e de disputa ideológica pelos seus fins e objetivos, o que envolvia, por conseguinte, repensar os próprios meios, a docência universitária foi se reconfigurando. Nesta época, segundo Machado (1999), salvo alguns raros casos, as aulas eram ministradas por meio de exposições eloquentes denominadas preleções. Prevalecia o autoritarismo professoral, bem como a ausência de preocupação do aluno como sujeito da aprendizagem, de modo que a memorização era a tônica do ensino. Diante desse quadro, muitos, entre eles os educadores e intelectuais ligados ao movimento da pedagogia escolanovista, criticavam o ensino ministrado nas universidades e clamavam por uma modernização didático-pedagógica, coerente com o desenvolvimento científico e as necessidades de uma sociedade que se modernizava. Machado descreve detalhadamente, em vários cursos, as mudanças que foram se procedendo a partir desse período, quando as aulas expositivas, não obstante tenham se mantido como o principal método de ensino, começaram a dar lugar para outras atividades, como aulas práticas, exercícios em sala de aula, excursões e seminários. Nesse mesmo estudo ${ }^{7}$, Machado (1999) mostra como a formação pedagógica universitária ganhou materialidade de fato somente nos idos da ditadura militar na década de 1970, em especial com a criação de laboratórios de ensino superior, de

\begin{tabular}{l|l|l|l|l|l} 
(C) Rev. HISTEDBR On-line & Campinas, SP & v.20 & $1-27$ & $\mathrm{e} 020007$ & 2020 \\
\hline
\end{tabular}


disciplinas de metodologia do ensino superior (sobretudo nos cursos de pós-graduação lato sensu), além do início da publicação de compêndios sobre a temática; contudo, esse processo se deu principalmente numa perspectiva tecnicista e prescritiva de ensino.

Machado (1999) identifica na passagem dos anos 1980 aos 1990 uma perda de fôlego desse discurso modernizante e a emergência de uma preocupação mais específica com os fundamentos da formação didático-pedagógica da docência universitária, movimento este que converge justamente com a constituição do campo da pedagogia universitária, quando começam a ser realizadas pesquisas mais sistemáticas sobre a prática pedagógica no ensino superior. Nesse percurso histórico de constituição da docência universitária, um dos elementos fundamentais que Machado procura apontar é como essa prática ao longo do tempo foi submetida a diferentes formas de disciplinamento e regulação, bem como veio a ser racionalizada em meio a aparatos de hierarquização, classificação e diferenciação, sempre legitimados por relações de poder e saber que tendem a naturalizar a realidade de tal prática.

\section{CONSIDERAÇÕES FINAIS}

Como ressalvado, não era objetivo deste artigo proceder com uma história detalhada da aula universitária, mas um esboço sobre seus determinantes históricos, de modo a apresentar elementos que nos ajudassem a desnaturalizá-la, a perceber as permanências e rupturas ao longo do tempo e atentar para questões que extrapolam o âmbito da aula e refletir como ela se apresenta como uma síntese de múltiplas determinações. A autonomia institucional e docente sempre foi relativa, variando os elementos constrangedores (por exemplo, a Igreja, o Estado e o mercado) e a intensidade do controle (lembrando que nos primórdios o mestre dominava mais completamente todo o processo de trabalho, dimensão que vai se perdendo com a divisão sociotécnica do trabalho, necessidade intrínseca do capital $^{8}$ ); as condições de trabalho nunca foram adequadas, com precarização mais intensa em certos momentos (com tendência a piora atualmente); o perfil e a carreira docente se transformaram com o passar dos séculos; o perfil estudantil democratizou-se com o tempo, embora muito controladamente; o número de alunos por "sala" aumentou; o currículo e o espaço pedagógico se alteraram; os métodos de ensino e os recursos didáticos modicaram-se (mais estes do que aqueles). Tudo isso provocou mudanças na dinâmica do processo educativo, ou seja, a aula ou a organização do trabalho didático que temos atualmente é produto de um longo processo histórico.

A universidade brasileira, como pudemos ver, é um fato histórico tardio em relação ao seu nascedouro, a Europa. A configuração do que veio a ser a aula universitária no Brasil em muito se deve à própria configuração da universidade europeia. No entanto, também vimos que as condições de produção da aula em nosso país têm lá suas especificidades; mais que isso, na medida em que a universidade como instituição de formação superior tende a se proliferar no Brasil somente a partir da década de 1930, a particularidade do seu processo de expansão e fixação - o processo acelerado e desorganizado de urbanização e industrialização de um país

\begin{tabular}{l|l|l|l|l|l} 
(C) Rev. HISTEDBR On-line & Campinas, SP & v.20 & $1-27$ & $\mathrm{e} 020007$ & 2020 \\
\hline
\end{tabular}


dependente da periferia do capitalismo -, é um produto da relação da singularidade de nossos determinantes históricos e sociais com a tendência universalizante da universidade europeia, de sorte que se almejamos compreender de maneira mais aprofundada a atual configuração da aula universitária no Brasil, temos a necessidade de uma apreciação mais detida da história recente da constituição de nossa educação superior, o que infelizmente não podemos fazer dentro dos limites de espaço que possuímos ${ }^{9}$. Desta feita, o que está ao nosso alcance é a enunciação de alguns elementos desse período histórico de constituição efetiva da universidade em território nacional os quais julgamos determinantes na configuração da aula universitária no Brasil.

Pois bem, após os anos 1930, alguns dos principais determinantes da configuração da aula universitária no Brasil foram, e em muitos casos continuam sendo:

- a criação de universidades com o objetivo de formar uma classe dirigente ilustrada;

- o surgimento de universidades sobretudo a partir da reunião formal de escolas superiores tradicionais com prestígio e poder;

- a construção de campi centrais, a partir de modelos preestabelecidos e de escassas discussões a respeito da arquitetura mais adequada às atividades pedagógicas, em que há o privilégio de locomoção por meio de automóvel, e com poucos espaços coletivos;

- sob influência da reforma universitária instaurada pela ditadura militar, os campi foram construídos em regiões mais distantes dos centros urbanos com o objetivo político de afastar a universidade das tensões mais candentes das cidades, bem como de fazer da reforma um instrumento de racionalização e diminuição dos custos, o que promoveu impactos diretos nas edificações das universidades, por exemplo, com a diminuição de suas dimensões ao reunir num mesmo lugar, compacto, professores-pesquisadores e funcionários técnico-administrativos de um mesmo departamento, e espalhando os estudantes pelo campus em diversas "centrais de aula" que não pertencem em última instância a nenhum departamento ou instituto específico, estando a serviço de todos, a depender das necessidades;

- a instituição do sistema departamental em detrimento do sistema de cátedras, passando do poder centralizado na figura do catedrático para o poder centralizado em órgãos colegiados, o que significou um processo modernizador e racionalizador, mas pouco democratizante;

- reunião de disciplinas afins num mesmo departamento, com oferta de cursos em um mesmo espaço e com menos custo material e humano (um docente para a mesma disciplina em diferentes cursos);

- implementação da matrícula por disciplina, pela lógica dos créditos, coerentemente com o processo racionalizador de oferta de uma mesma disciplina para diferentes cursos, com aumento da "produtividade" didática e diminuição das resistências e possibilidades de organização dos sujeitos envolvidos, em especial os estudantes; 
- com o sistema de créditos e matrículas por disciplinas vinculadas a departamentos, em tese os alunos teriam maior liberdade para escolher suas disciplinas no seu percurso dentro do curso, mas além de não ter informação/orientação suficiente e qualificada para pensar qual seria o melhor percurso, os pré-requisitos e disciplinas semestrais amarram os estudantes, dificultando um trânsito mais fluido pelo currículo;

- contraposição, com tendência à burocratização, entre o departamento (pensado mais na lógica da pesquisa, mesma área de conhecimento) e a coordenação de curso (pensado mais na lógica do ensino, estruturação do currículo);

- os professores se ligam aos departamentos e os alunos às disciplinas e ao curso, de sorte que o sistema de créditos parcela o curso universitário tal como o trabalho é parcelado nas empresas e fábricas;

- o tempo do aluno tem de se conformar à estrutura de calendários, horários e sequências didáticas que pouco ou nada dialogam com a dimensão aberta de sua atividade, de sua experiência com o conhecimento; essa fragmentação, normalização e recomposição do tempo do aluno na forma de um quebra-cabeças não planejado por ele (e talvez nem mesmo pelo professor) tende a esvaziar de sentido e compreensão o processo formativo;

- o contato com obras clássicas das respectivas áreas do conhecimento é cada vez mais substituído por leituras fragmentadas e aligeiradas de textos e manuais de pouco aprofundamento teórico e histórico, coerente tanto com um currículo tendencialmente parcelado quanto com uma produção acadêmica refém do produtivismo "lattesiano"10.

Enfim, esses elementos recentes do processo histórico de constituição da universidade brasileira $^{11}$, e a lista poderia se alongar ainda mais, nos permitem ter uma ideia da complexidade das múltiplas determinações da aula na universidade. Por trás, por exemplo, de uma indagação de um aluno a um professor a respeito de uma sobreposição de conteúdo ou do pouco tempo disponível de estudo, ou mesmo da constatação da superlotação de uma sala de aula, encontramse, exagerando um pouco, todavia com respaldo histórico, o capital, a burocracia estatal e a ditadura militar. Isso porque não comentamos sobre o terreno espinhoso, e muitas vezes pantanoso, das famigeradas tecnologias de comunicação e informação, que certamente trazem novos elementos configuradores da aula universitária, bem como sobre o processo intensificado de mercantilização da universidade e de decadência e burocratização das condições de trabalho docente. Ora, não por acaso proliferam as tais pedagogias das competências, focalizadas nas noções abstratas de "aprender a aprender" e "educação ao longo da vida", totalmente esvaziadas de uma perspectiva realmente crítica e científica, deslocando o polo do ensino para o polo da aprendizagem, com a consequente supervalorização das dimensões psicológicas do processo educativo em detrimento das condições materiais e objetivas, as quais tendem a se deteriorar nesse âmbito. 
Como é possível (re)pensar a aula universitária sem todos esses determinantes históricos (dos mais antigos aos mais recentes) em mente? Tal como defende Alves (2005), inspirado em Rugiu (1998), não se trata de cairmos em certa nostalgia de um período histórico em que a atividade docente possuía um caráter artesanal, e em que os alunos tomavam contato aprofundado com os clássicos de sua área, sem a pressão do controle do tempo do capital e todo o aparato tecnológico de nossos dias. As tecnologias mais avançadas estão aí, e certamente alterando a relação pedagógica e a organização do trabalho didático, muitas vezes para pior. Contudo, o tempo do "mestre artesão" passou, as condições de produção da aula universitária são outras: a história é um processo irreversível.

Neste caso, quais os determinantes históricos, quais os limites e possibilidades da aula universitária - como cada um dos momentos de consecução da relação educativa que se dá no encontro de uma forma histórica de educador com uma forma histórica de educando(s), num espaço físico determinado, e com a mediação de recursos didáticos específicos, para retomarmos o nosso conceito de aula - na atual quadra histórica brasileira? Assim, defendemos que a crítica da prática pedagógica, elaborada pelo campo da pedagogia universitária, se realize precisamente no enfrentamento crítico das atuais formas de organização do trabalho didático na universidade, o que significa questioná-la como instituição, caso contrário, a tão propalada inovação pedagógica não passará de mais um processo de adaptação à nova configuração da ordem gerencial vigente. Destarte, a construção de condições que permitam a produção da aula universitária demandada por nossa época depende de uma crítica radical da aula universitária de nosso tempo presente, o que só é possível por meio da compreensão de seus determinantes históricos mais profundos, ou seja, da análise da organização (capitalista e dependente) do trabalho didático na era da barbárie do capital-imperialismo. (FONTES, 2010). Dentro de seus limites, a intenção deste artigo foi oferecer uma singela contribuição a tal compreensão.

\section{REFERÊNCIAS}

ALVES, G. L. O trabalho didático na escola moderna: formas históricas. Campinas: Autores Associados, 2005.

ALVES, G. L. Organização do trabalho didático: a questão conceitual. Acta Scientiarum, Education, v. 34, n. 2, p. 169-78, 2012.

BROCKLISS, L. Curricula. In: RUËGG, W. (org.). A history of the university in Europe, v. II, Universities in early modern Europe (1500 - 1800). Cambridge: Cambridge University Press, 2003.

CHARLE, C.; VERGER, J. História das universidades. São Paulo: Editora Unesp, 1996.

CHAUI, M. Escritos sobre universidade. São Paulo: Editora UNESP, 2001. 
COÊLHO, I. M. A gênese da docência universitária. Linhas Críticas, Brasília, v. 14, n. 26, p. 5-24, 2008.

CORREA, G. T. Os labirintos da aula universitária. 2016. 354 f. Tese (Doutorado em

Educação) - Faculdade de Educação, Universidade de São Paulo, São Paulo, 2016.

CUNHA, L. A. A universidade temporã: o ensino superior, da Colônia à Era Vargas. 3. ed. São Paulo: Editora Unesp, 2007.

FÁVERO, M. L. A. A universidade no Brasil: das origens à Reforma Universitária de 1968.

Educ. rev. n. 28, p. 17-36, 2006.

FERNANDES, F. A questão da USP. São Paulo: Brasiliense, 1984.

FERNANDES, F. Universidade brasileira: reforma ou revolução? São Paulo: Alfa-Omega, 1975.

FONTES, V. O Brasil e o capital imperialismo: teoria e história. 2. ed. Rio de Janeiro: EPSJV/Editora UFRJ, 2010.

FREITAS, L. C. Crítica da organização do trabalho pedagógico e da didática. Campinas, SP: Papirus, 1995.

FRIJHOFF, W.; Patterns. In: RUËGG, W. (org.). A history of the university in Europe, v. II, Universities in early modern Europe (1500 - 1800). Cambridge: Cambridge University Press, 2003.

GIEYSZTOR, A. Management and resources. In: RIDDER-SYMOENS, H. (org.). A history of the university in Europe. v. 1. Universities in the Middle Ages. Cambridge: Cambridge University Press, 1992.

LIBÂNEO, J. C. Didática. 2. ed. São Paulo: Cortez, 2013.

MACHADO, A. B. Arqueografia da docência universitária. 1999. Tese (Doutorado em Educação) - Faculdade de Educação, Universidade Federal do Rio Grande do Sul, Porto Alegre, 1999.

MANACORDA, M. A. História da educação: da antiguidade aos nossos dias. 5. ed. São Paulo: Cortez, 1996.

MINTO, L. W. A educação da miséria: particularidade capitalista e educação superior no Brasil. São Paulo: Outras Expressões, 2014.

PINTO, G. A.; BUFFA, E. Arquitetura e educação: câmpus universitários brasileiros. São Carlos: Ed. UFSCar, 2009. 
PINTO, G. A.; BUFFA, E. Arquitetura, urbanismo e educação: campi universitários brasileiros. In: VI CONGRESSO LUSO-BRASILEIRO DE HISTÓRIA DA EDUCAÇÃO, 6. 2006, Uberlândia, MG. Anais [...]. Uberlândia, MG, 2006.

PONCE, A. Educação e luta de classes. 16. ed. São Paulo: Cortez, 1998.

RUËGG, W. Themes. In: RUËGG, W. A history of the university in Europe, v. II, Universities in early modern Europe (1500 - 1800). Cambridge: Cambridge University Press, 2003.

RUGIU, A. S. Nostalgia do mestre artesão. Campinas: Autores Associados, 1998.

SAVIANI, D. Ensino público e algumas falas sobre universidade. 5. ed. São Paulo: Cortez: Autores Associados, 1991.

SILVA, E. F. Docência universitária: a aula em questão. 2009. Tese (Doutorado em Educação) - Faculdade de Educação, Universidade de Brasília, Brasília, 2009.

SIMONE, M. R. Admission. In: RUËGG, W. (org.). A history of the university in Europe, v. II, Universities in early modern Europe (1500 - 1800). Cambridge: Cambridge University Press, 2003.

TUMOLO, P. S.; FONTANA, K. B. Trabalho docente e capitalismo: um estudo crítico da produção acadêmica da década de 1990. Educ. Soc. v. 29, n. 102, 2008.

VANDERMEERSCH, P. A. Teachers. In: RUËGG, W. (org.). A history of the university in Europe, Vol. II, Universities in early modern Europe (1500 - 1800). Cambridge: Cambridge University Press, 2003.

VERGER, J. As universidades na Idade Média. São Paulo: Editora Unesp, 1990.

VERGER, J. Cultura, ensino e sociedade no Ocidente nos séculos XII e XIII. Bauru, SP: Edusc, 2001.

VERGER, J. Patterns. In: RIDDER-SYMOENS, H. (org.). A history of the university in Europe. v. 1. Universities in the Middle Ages. Cambridge: Cambridge University Press, 1992a.

VERGER, J. Teachers. In: RIDDER-SYMOENS, H. (org.). A history of the university in Europe. v. 1. Universities in the Middle Ages. Cambridge: Cambridge University Press, 1992b. 


\section{Notas}

${ }^{1}$ Doutorado em Educação pela Universidade de São Paulo (USP). Professor contratado da Faculdade de Educação da Universidade de São Paulo (FE/USP). Contato: correa.gt@usp.br.

${ }^{2}$ Pós-doutorado em Formação de Professores para a Educação Superior pela Universidade Autônoma de Barcelona (UAB). Professora Associada Sênior da Faculdade de Educação da Universidade de São Paulo (FE/USP). Contato: mialmei@usp.br.

${ }^{3}$ Para um trabalho na mesma direção que o nosso, mas segundo referencial teórico e abordagem do objeto diversos, conferir Silva (2009).

${ }^{4}$ Alves (2005, p. 25) argumenta que neste período inicial de sua história (até o final do século XV), a universidade ainda não trabalhava com um ensino seriado, de tal forma que o ensino se realizava pelo modus italicus, muito ligado ao modelo de formação das corporações de artes e ofício: "O mestre passava a atender um conjunto de discípulos, mas estes não eram subdivididos por níveis de domínio do conhecimento. Os recém-chegados incorporavam-se aos mais antigos e ouviam as mesmas lições. Nos anos subsequentes o mesmo ritual se repetia. Não existiam classes, portanto, associadas a níveis de formação dos estudantes. As dificuldades dos discípulos eram tratadas por um auxiliar do mestre, função atribuída, normalmente, a um instrutor ou estudante mais adiantado. $\mathrm{O}$ ensino era ministrado em latim e a memorização das lições era entendida como um passo essencial da aprendizagem".

${ }^{5}$ Sobre a história dos diferentes títulos universitários, conferir Charle e Verger (1996, p. 35-6).

${ }^{6}$ Para detalhes sobre esse método, conferir Verger (2001, p. 269-71).

${ }^{7}$ Ponto que desenvolvemos com mais profundidade na pesquisa original. (CORREA, 2016).

${ }^{8}$ Para um aprofundamento nessa questão no que diz respeito ao nosso tema, conferir os trabalhos de Alves (2005, 2012), onde o autor remonta a Comênio os primórdios da perda do controle do processo de trabalho docente, especialmente pelo advento do manual didático.

${ }^{9}$ Para uma discussão mais desenvolvida a respeito desse período histórico, indicamos à leitora e ao leitor a pesquisa original que inspira este artigo. (CORREA, 2016).

${ }^{10}$ Remetemos, novamente, aos trabalhos de Alves $(2005 ; 2012)$ e sua crítica ao manual didático, neste caso como perda do acesso ao conhecimento culturalmente significativo.

${ }^{11}$ Conferir: Chaui (2001), Fávero (2006), Fernandes (1975; 1984), Minto (2014), Pinto e Buffa (2009), Saviani (1991). 